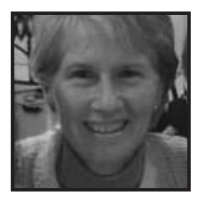

\title{
Autonomy Building Through Peer Tutoring: Second Language Students Engage in Literacy Learning
}

Joanne Kingsley, Bishop's University

\section{ABSTRACT}

Research indicates that direct instruction of literacy skills benefits all learners, especially second language learners and students with learning challenges; however, students become disengaged when skills are taught through repetitive drill and skill practice in isolation from meaningful contexts. This article examines the critical pedagogy of an elementary classroom teacher as she engaged students in a peer tutoring reading program that developed learners' autonomy and self-esteem.

$\mathrm{n}$ recent years there has been a move away from whole language teaching and a return to basic skills instruction due to lowered achievement scores on standardized tests (Freppon \& Dahl, 1998). The No Child Left Behind legislation in the United States has resulted in mandatory literacy skills instruction for ninety minutes daily in many schools (Love \& Fiedler, 2005). Teaching skills in this manner is a disturbing trend since it isolates skills instruction and sets it apart from a meaningful context within which learners can situate their learning (Street, 1984; Twiss, 1996). Research indicates that direct instruction of literacy skills benefits all learners, especially second language learners and students with learning disabilities (Huie \& Yahya, 2000); however, students become disengaged when faced with repetitive drill and skill practice. This article will describe a peer tutoring program that Cathy (a pseudonym), a grade 2/3 teacher from a school in Southern Quebec, used to promote the engagement of second-language learners as they 
learned to read. By personalizing her curriculum and pedagogy, embedding skills instruction within a meaningful context, initiating a teaching/learning cycle through peer tutoring, and responding to individual needs, Cathy supported her students in becoming self-regulated literacy learners.

\section{Situating the Study}

My qualitative inquiry of Cathy's literacy practices took place over the course of one school year as part of my doctorate. The photograph below depicts Jean Marc (a pseudonym) reading a book to his first-grade peer tutoring partner as part of an adapted literacy program designed by Cathy to meet special needs of individual learners. I will describe this and other literacy practices throughout this article in an attempt to clarify ways in which Cathy successfully engaged students in their literacy development.

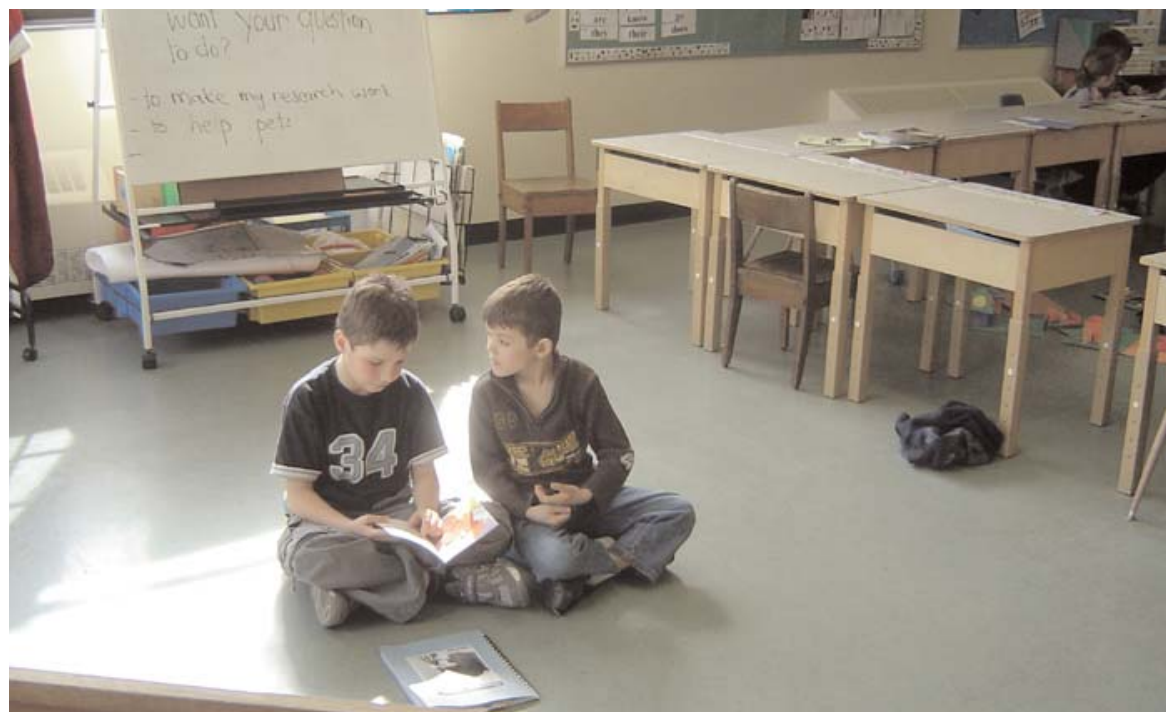

Fig.1: Peer tutoring program

Pleasant View Elementary School (a pseudonym for the school in the study) is a vibrant school situated in a thriving city in Southern Quebec with over five hundred students and thirty teaching staff. The school offers an English education to a mainly French-speaking student population. A Language Arts consultant from the school board recommended Cathy as an outstanding teacher who was well known for her exceptional teaching practice. 
Nineteen of the twenty children in Cathy's class spoke English as a second language. French was the first language of all but one of the nineteen students, although a number of parents spoke both French and English. Over $90 \%$ of the class began kindergarten as unilingual francophone students; however, by the time they reached second grade they communicated well in English. Students in both grades began the year below grade level in reading and writing and all eight children in third grade followed Individual Education Plans (IEP) to support their special learning needs.

I made twenty-five visits to observe Cathy's classroom during the two-hour Language Arts period in the morning from January to June and part way through the study I selected six children to study in greater depth than the rest of the class. These children seemed to emerge gradually as ones that drew my attention. I chose four children who had the greatest learning difficulties. I thought that their literacy behaviors might reveal facets of the literacy program that would otherwise remain hidden with students who were able to read and write more easily. Jean Marc, Marie and Sylvie (pseudonyms) were third grade students who faced learning challenges and needed the support of a teacher aide for at least half an hour a day, four days a week. They had difficulty processing language and were unable to decode or encode print. Robert, also a third grade student, had a hearing impairment that required Cathy and the other children to use a microphone that amplified the sound through his headphones. I also chose Philippe and Charlotte, second grade students. Charlotte was a bright girl who read, wrote and spoke quite well in English, while Philippe had begun the year in great frustration and felt unable to express his ideas in English either orally or in writing. The first language of five of the children was French and I felt they represented typical challenges faced by the majority of students in Cathy's class.

\section{Methodology}

For my inquiry, I decided to create a case study using grounded theory, a form of analysis that elicits themes from the data, narrative analysis that builds contextualized stories from the data, and visual ethnography (see below) as complementary research approaches. A case study is "an exploration of a 'bounded system' or a case (or multiple cases) over time through detailed, in-depth data collection involving multiple sources of information rich in context" (Creswell, 1998, p.61).Visual ethnography (Harper, 2003; Prosser, 2007) is a particular approach that utilizes photographs, film and other digital media environments to learn more about people and 
their world (Goldman-Segall, 1998). Visual images and technologies were both the method of exploring and the means of representing ethnographic knowledge (Pink, 2001). As participant observer, I collected data by photographing, video- and audiotaping, and interviewing both Cathy and her students. I often stood at the back of the room to videotape but also circulated in the class to observe students' behaviors more closely. I used these images in conjunction with transcriptions of interviews, instructions and student dialogue during my analysis and in representing my findings.

\section{Defining Engagement}

Before describing the peer tutoring program, I shall explain my conception of engagement. Engagement is focused attention and perseverant commitment to learn that includes a sense of pleasure and enjoyment in the "doing" (Newmann, as cited in Vibert \& Shields, 2003; Reeve, Jang, Carrell, Jeon \& Barch, 2004). It includes intrinsic motivation in the sense that engaging in a task is initiated by an inner desire to learn, understand, or accomplish some intention and consequently results in the ability to sustain interest and active involvement in an activity (McMahon, 2003). Engaged behavior is demonstrated by an eagerness to enter into a task and a quickness to settle into a concentrated effort to think critically and reflectively about the activity. Because the task is of personal interest and relevance, the individual is unwilling to abandon the task easily; on the contrary, an engaged learner will invest extra time and energy to persevere even when faced with obstacles and frustration.

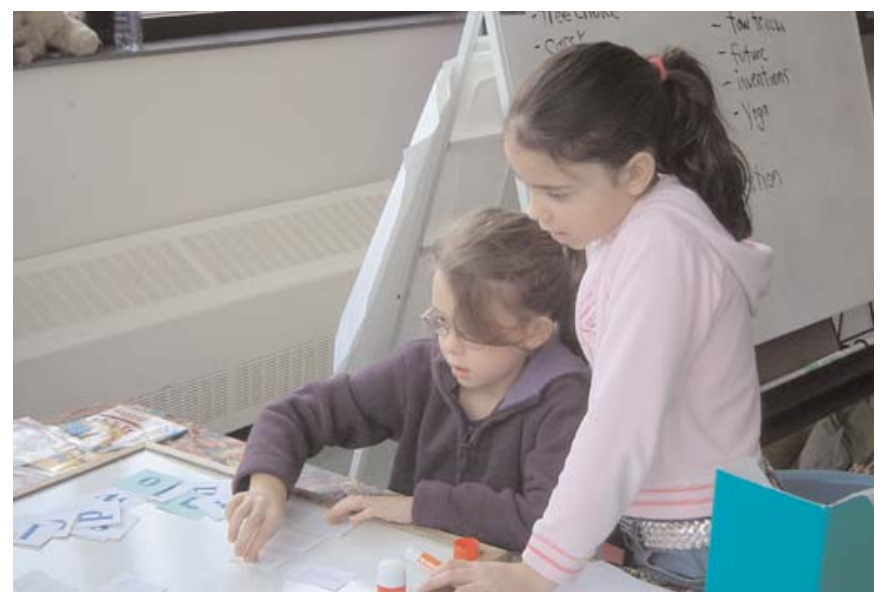

Fig. 2: Sustained interest and active involvement 
I think it is important at this point to situate engagement within a broader conceptual framework. The above definition could be applied within any of the three paradigms outlined by Vibert and Shields (2003), a technical/rational, interpretist or critical perspective. The technical/rational conception is an approach to teaching and learning that maintains teacher autonomy in the transmission of a mandated curriculum; an interpretist perspective is more student-centered in that students are offered more opportunities to make choices within the classroom curriculum. Critical pedagogy, on the other hand, questions issues of power and voice with the goal of raising awareness of democratic rights of all learners regardless of race, gender, ethnicity, or ability. This latter framework invokes a form of critical reflection that accepts honest discussion of sensitive issues and offers a forum for agentative transformation of society. Offering equal access and opportunities for all learners from differing backgrounds and abilities in a safe, caring environment is necessary for a just, democratic and empathetic education (Kincheloe \& Steinberg, as cited in Vibert \& Shields, 2003).

Critical pedagogy is particularly relevant to this study because it "challenges social structures and exposes inequities and inconsistencies between stated intentions and realized commitments of existing social institutions such as schools" (McMahon, 2003, p. 262). The Quebec Education Program (2001) advocates "success for all"; however, many children in today's schools face learning challenges that are further exacerbated by being English language learners. Students with learning disabilities such as dyslexia "need carefully constructed, individual instructional programs" that will enable them to fully participate in and beyond classroom life (Hehir, 2007, p.14). Unfortunately, some teachers are insufficiently prepared to address the diversity of emotional, academic and behavioral needs of these learners. Furthermore, teachers holding a deficit notion of students with learning challenges (Pardoe, 2000) lower expectations and children, stigmatized by being labeled disabled, lose confidence and self-esteem (Harry \& Klingner, 2007). They gradually become disinterested in participating in a curriculum that offers only "token gestures toward inclusivity" (McMahon, 2003, p. 263). Teachers need to develop not only effective literacy strategies but also a critical stance in moral and ethical concerns in literacy instruction especially in addressing the needs of minority cultures and at-risk student populations (Harris \& Graham, 1994; Leland, Harste, Jackson, \& Youssef, 2001).

Peer tutoring has improved both academic achievement and behavior in students with emotional and behavioral disorders (Barton-Arwood, Wehby, \& Falk, 2005; Kreuger, 1996; Kreuger \& Braun, 1998, Kreuger \& Townshend, 1997). Peer-assisted learning strategies (PALS) for English language learners with learning disabilities have resulted in substantial improvement in reading comprehension (Saénz, Fuchs, \& 
Fuchs, 2005). This study provides a description of a peer tutoring program that embeds skills and strategy instruction within meaningful, functional reading and writing experiences, an approach that has proven to be an effective, balanced method of teaching literacy skills (Dahl, Scharer, Lawson, \& Grogan, 1999).

\section{Personalizing Curriculum and Pedagogy}

Teachers need to get in touch with their educational philosophies in order to live out their personal values and beliefs in the classroom with integrity. Doing so creates a sense of harmony and balance in their interactions with students and in the way they choose to interpret and enact their curriculum. Cathy believed that "children are by nature smart, energetic, curious and eager to learn.... They learn best when they are happy, active, involved and interested in what they are doing" (Holt, as cited in Morgan \& Saxton, 1994, p. 18). She admitted that "these kids are sweet, good, hardworking and generous" and her sincere affection for them was evident in the way she tousled Jean Marc's hair, or gently placed her arm around a child's shoulder.

Cathy didn't want "to be the authority all the time" and stated, "My ultimate goal for these children is that they become independent." Her perception of children reflected a basic tenet of self-determination theory-that people are "curious, vital, and self-motivated. At their best they are agentic and inspired. They strive to learn, extend themselves, master new skills, and apply their talents responsibly" (Ryan \& Deci, 2000, p. 68). All of these attributes are reflective of individuals who are fully engaged in learning, and research has shown that teachers who support student autonomy foster a learning environment that nurtures student engagement.

Cathy lived out the notion that knowledge is emergent, developmental and partial, (Bruner, 1996; Fosnot, 2005; von Glaserfld, 2005; Schwandt, 2003) and this "radical idealistic perspectivism" (Good \& Brophy, 2003) allowed her to operate from a place of rest. This resting place created a relaxed, pleasurable atmosphere in the classroom where children could learn within social communities of discourse without having to endure the tension of unrealistic expectations that exist when a teacher puts a mandated curriculum before learners. Cathy said, "Children drive the learning" and recalled an incident in which she had attempted to correct every example in an assignment. "It was excruciatingly dull and boring. I was bored. And you could see their eyes just rolling too." As a result, she allowed students to correct work in partners and discuss answers rather than dictate answers ad nauseam. 
Realizing that understanding and competency develop slowly over time, Cathy planned engaging literacy events such as the peer tutoring program that challenged learners to acquire reading skills within the authentic context of teaching younger students how to read. Through the peer tutoring program, children learned to function independently with their tutees.

\section{Developing Literacy Skills Through Books and Buddies}

Cathy taught literacy skills through a peer tutoring program called Books and Buddies (Kreuger \& Braun, 1998). This reading program was developed by two of Cathy's colleagues in an attempt to help the francophone population learn to speak and understand English as they learned how to read. It is a highly structured program in which children are partnered in a one-on-one interaction, reading to each other and engaging in cognitively challenging literacy activities that enhance reading skills.

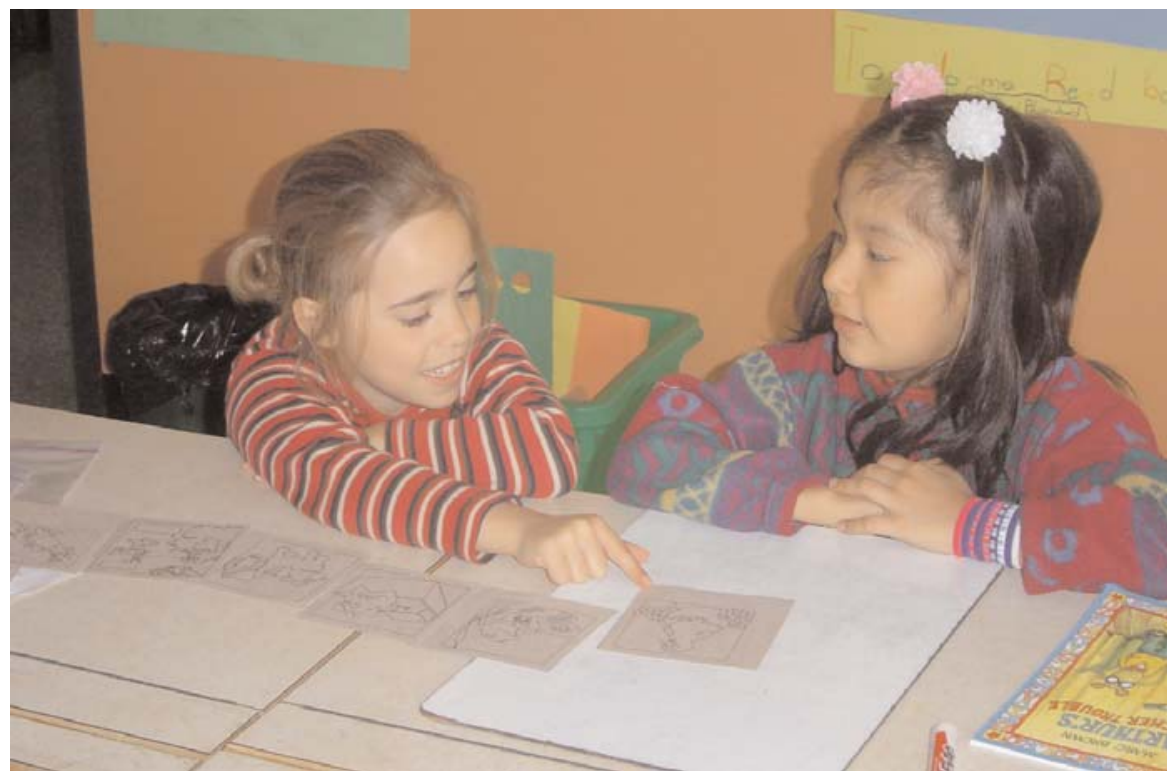

Fig. 3: Partners actively engaged in sequencing activity 
Research supports the use of peer tutoring as an effective strategy for teaching reading skills (Barton-Arwood, Wehby, \& Falk, 2005; Kreuger \& Braun, 1998). The main objective of the program is to increase and improve reading fluency among second language learners. According to Kreuger \& Braun (1998), it aims to:

- Provide each child with the opportunity to read and practice English for 30 minutes a day

- Provide an atmosphere where children would find reading pleasurable and thereby come to love to read

- Train the children in appropriate reading behavior and reading strategies through mini-workshops so that the peer-tutoring time would be effective

- Develop positive social skills, recognizing that children learn best when they feel good about themselves and see themselves as successful

- Improve the children's spelling skills

- Introduce the children to different genres of texts

- Improve the children's writing (p.410)

Kreuger and Braun's research $(1996,1998)$ and my study (Kingsley, 2007) indicate very positive results in attaining all of these objectives.

Cathy's students worked with first grade children. In November, Cathy and the first grade teacher, Norma, met together to plan the peer tutoring program for the year. The collaborating teachers prepared an agenda, a two-sided, six-page booklet outlining the sequence of activities for a four-day period. They carefully partnered the children according to their abilities and needs and maintained these dyads for approximately three months at which time they changed partners taking into consideration compatibility of both personalities and reading skills. The dyads were divided into two groups, meeting in one of the teacher's classrooms for thirty minutes a day, four days each week. In March, Cathy's class helped to train the first grade children to become big buddies with the kindergarten class by practicing the kindergarten agenda with the first grade students.

\section{Preparation for Books and Buddies}

Cathy prepared her class for the first visit by having students generate a list of interview questions to get to know their buddy. Both teachers demonstrated how 
to give supportive feedback and friendly greetings. Part of developing self-regulated behaviors included organizing reading materials each day. The children were responsible for checking that they had their agenda, reading books, white boards, markers, and activity sheets.

Phonemic awareness, phonics and spelling were all components of Cathy's literacy program. To crack the alphabetic code of the English language, children need to learn about phonemes (sounds), graphemes (letters), and graphophonemic (lettersound) relationships. Tompkins (2006) explains that children

...learn graphophonemic relationships as they match letters and letter combinations to sounds, blend sounds to form words, and decode and spell vowel patterns.... [S]tudents actually develop three separate but related abilities about the alphabetic code:

Phonemic awareness. The ability to notice and manipulate the sounds of oral language. Children who are phonemically aware understand that spoken words are made up of sounds, and they can segment and blend sounds in spoken words.

Phonics. The ability to convert letters into sounds and blend them to recognize words. Children who have learned phonics understand that there are predictable sound-symbol correspondences in English, and they can use decoding strategies to figure out unfamiliar written words.

Spelling. The ability to segment spoken words into sounds and convert the sounds into letters to spell words. Children who have learned to spell conventionally understand English sound-symbol correspondences and spelling patterns, and they can use spelling strategies to spell unfamiliar words. (p. 115)

Developing all three abilities is essential for an effective literacy program for young children (National Reading Panel, as cited in Tompkins) and Cathy incorporated these elements into her literacy instruction. The graphophonemic awareness program offered children opportunities to identify and categorize sounds in words through a number of different games over the course of the week. One type was a memory game in which the child had to discover matching pairs of words from sound families. A second board game required the younger child to write only the first and last sound of a word on a small dry-erase (white) board as it was dictated by the older 
partner. Cathy also taught her class how to sort words into sound families by cutting and gluing words into their notebooks (Bear and Templeton, 1998). They then led their buddies in a similar activity.

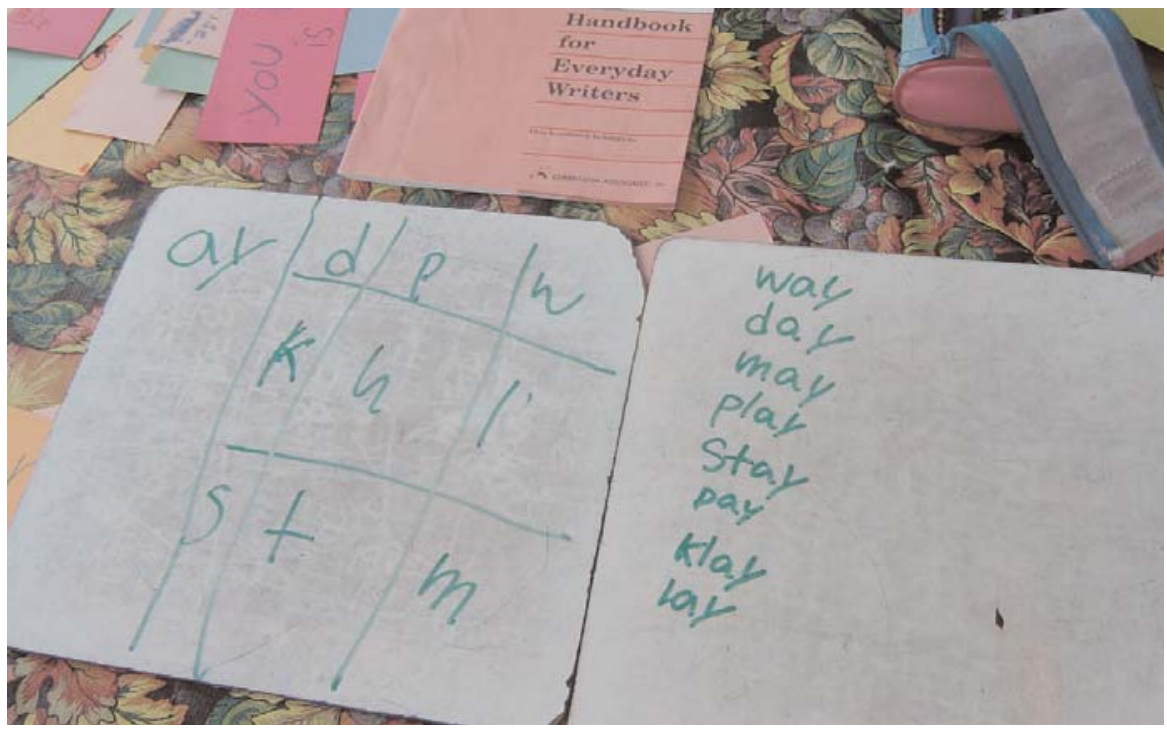

Fig. 4: Graphophonemic activity

Because these skill-building activities were designed in a game format, the children found them engaging and fun.

\section{Teaching/Learning Cycle}

These elements were taught through a dynamic teaching/learning cycle. This term refers to the way in which Cathy initiated a cyclical process of teaching and learning that included students and their peer tutoring partners. Second and third grade students were given opportunities to learn particular skills and subsequently teach these skills to their peer tutoring buddies. Often Cathy began by instructing the entire class and then moved the learning process to small groups or individuals working to practice the concept or skill. After a short time period the class regrouped as a whole to share what they had learned and Cathy provided feedback on their learning. There was a constant flow between teacher-directed whole class instruction to small group or individual teaching/learning interactions and then back to whole class wrap-up sessions. 
Cathy's teaching methods maximized student engagement. She generally used an inductive, indirect approach for whole-class instruction calling on individuals to provide information to co-construct knowledge together (Wells, 1999, 2000); however, when preparing children for Books and Buddies she often used direct teaching and modeling to ensure students understood how to proceed with their buddies. The inductive approach precluded a passive response by students since they were required to draw upon their prior knowledge to answer probing questions. Modeling evoked an active involvement on the part of the children as they roleplayed their little buddies' responses.

An example of Cathy's indirect approach occurred when she reviewed long vowel sounds. Instead of telling the class what a long vowel sound is, Cathy asked the students to define the term. Richard defined the term but was unable to provide a correct example. Cathy redirected his understanding through questioning strategies:

C: Just get your white boards and your markers and we're going to do something for about fifteen minutes before we prepare for buddies. You are going to work to find as many words as you can. And remember, I'm thinking of long vowel sounds. Of course, you can make any words. But, try and focus on the long vowel sounds. Can anybody tell me what may make the long vowel? Richard?

R: It says its name.

C: It says its name. Yes. What would it look like in a word?

R: $\quad$ Like apple. A says its name.

C: $\quad$ Say that word again?

R: Apple.

C: What letter says its name?

R: $\quad$ The $A$.

C: $\quad$ So, are you sure that's a good example? Because, you would have to say Aepple. What about the word, Richard? What about just this word? (Cathy wrote the word ape on the white board) Is that a long vowel? Is the $A$, a long vowel there or a short vowel? Just listen, everybody. In the word, APE. Is it a long $A$ sound?

Once Cathy clarified the children's understanding of long vowel sounds, she asked them to list as many words as they could and check them in the dictionary. She then circulated and monitored students' progress during their collaborative interactions. Students' focused dialogue drew them into the learning process as they explored possible answers. Checking their dictionaries prior to the final large-group 
discussions further sustained their interest in the activity since they were curious to determine the accuracy of their initial attempts to find correct examples. The whole class session at the end of the activity provided Cathy an opportunity to clarify and correct misconceptions that she had noticed as she observed students' work so that students felt self-assured when they tutored their learning partners.

The chart below indicates the cognitive challenge of this type of activity when the children had to generate their own examples of silent e words using the letters on the chart.

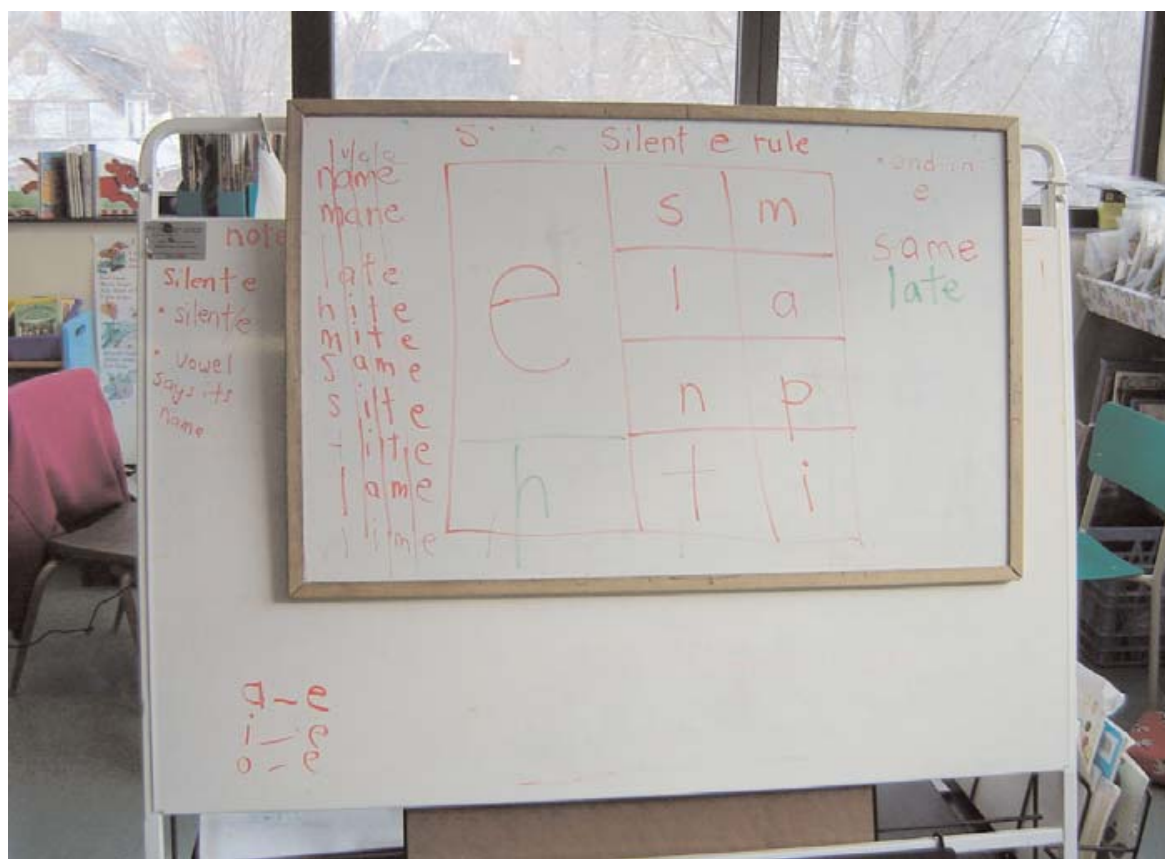

Fig. 5: Concentrated effort required for cognitive challenge

The children valued this teaching/learning cycle as it gave them the authority to be little teachers. This was especially the case during peer tutoring. Both Cathy and Norma prepared the children well for the day's exchange. Just prior to the buddies' arrival in class, they reviewed the agenda, modeled how to teach the particular literacy skills for the day, and gave students time to practice. The partners felt confident in their teaching and from the many classes I observed performed their role effectively. 
To illustrate this aspect of the teaching/learning cycle, I shall provide a glimpse of an interaction between two students, Rachel, a second grade child, and Alice, a first grade student, as well as the preparation Cathy gave Rachel prior to Alice joining her. Cathy began by explaining to the class that they had a new phonemic awareness sheet to work on during Books and Buddies. She asked the children to read the instruction sheet with her together as a class and then individually:

C: $\quad$ This is going to be for this week. What you can do with your grade 1 buddy....we'll use this one. Look at the first one that says number 1 . Put your finger on it please so I can see ... Make $R$... Read it with me please.

C/St: Make $R$, say car. Make car, say far. Make far, say bar. Make bar, say star.

C: Read that yourself one more time. Go back and read it to yourself silently.

(THE CHILDREN READ THIS OUT LOUD AGAIN ALL TOGETHER)

C: Okay, let's go where it says number 3. Please put your finger on it so I know everybody is reading the same thing. Because it's tricky. We've changed your phonemic awareness a little bit now. Say MUST without the $T$. So, do it yourself please. Say MUST without the T. The next one. Okay, I'm the big buddy, you're the little buddies. So, you have to answer, okay. Hey, little buddies. Say SLEEP without the P.

St: SLEE.

C: $\quad$ Say FLAG without the G.

St: FLA.

C: $\quad$ FLA.That's it ... good. Okay. That's what you're going to do with them today.

The excerpt from the transcript illustrates the careful planning Cathy did to prepare the children for the peer tutoring program as she explained the activity and demonstrated how to enact the new phonological skills.

When Rachel and Alice, her first grade partner, began this activity shortly after Cathy prepared the class, Rachel was an effective teacher for her partner. Since the activity was new for Alice, she had difficulty grasping the instruction to drop the final sound in the word. Rachel corrected her mistakes and helped Alice understand how to identify the changed ending sound:

R: Okay. Say SLEEP.

A: SLEEP. 
R: Without the $P$.

A: EEP, LEEP.

R: SLEE.

A: SLEE.

R: Okay. Say FLAG.

A: FLAG.

R: $\quad$ Without the $G$.

A: FLAG.

R: No. It's, because I said to you to take out the G. So, you say FLA not $A G$, okay?

A: FLA.

I found this teaching exchange insightful as it demonstrated that children can effectively teach their peers in a self-regulated manner when they have structured support (Reeve, Jang, Carrell, Jeon \& Barch, 2004). Cathy's instructions were clear, detailed and informative. Students received explicit instructions and demonstration of expected teaching strategies prior to the tutoring, agendas that listed the sequence of activities, and phonemic awareness sheets that outlined the words to be used for the lesson. This brief episode illustrates the power of the teaching/learning cycle in maximizing the engagement of students in literacy learning since they were intrinsically motivated to attend to instructions in order to perform their teacher roles with their learning partners.

\section{Positive Emotional Quality of Engaged Students}

One sign of engagement is the "emotional quality of a person's active involvement in a task" (Reeve et al., 2004, p. 147). Although some of the students in Cathy's class began the year experiencing great frustration due to their inability to read or write at level, their negative attitudes towards literacy changed into ones of pleasure and positive self-esteem as they learned how to read and spell.

Phonics abilities were strengthened through a procedure in which younger buddies dictated their power words (most frequently used words) to the big buddies who wrote them on small white boards. The first grade students were taught to meticulously check the spelling by making a check mark above each written letter. The children were very focused as they engaged in this spelling activity and the photographs below illustrate the enjoyment they had while doing their work. 


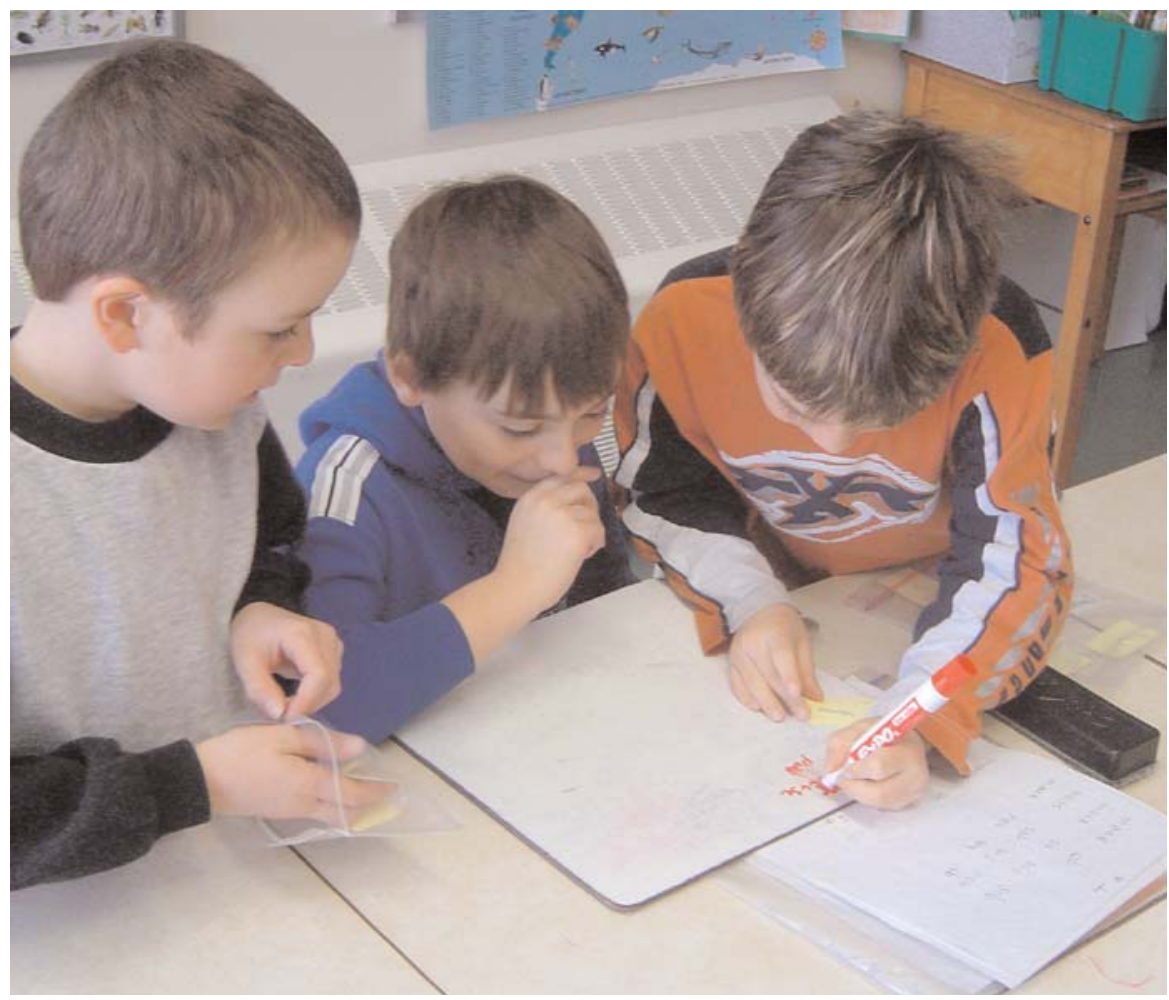

Fig. 6: Active, enjoyable involvement in checking spelling

Cathy taught her class reading strategies such as predicting, using illustrations, skipping the word and reading ahead, and finding smaller words within bigger words. Her students also learned other reading strategies such as retelling stories, sequencing illustrations, and answering comprehension questions. All of these reading skills were taught within the context of the peer tutoring program and the children valued their importance since they realized that they would be teaching these strategies to their buddies. Consequently, they were positively energized to acquire reading skills and delighted in assuming personal responsibility for tutoring their partner (Reeve et al., 2004).

Early in the year, the big buddies read a book several times to the little buddies and taught their partners how to point to words as they were reading. By the end of the week, the younger children were able to read the book by themselves. From January to June, both members of the dyad self-selected a book to read to their partner. Both Cathy and Norma strongly believed in the importance of allowing the 
children to make their own choice of books in order to maintain their autonomy in the reading process and also to foster a love of reading. They taught their students how to choose books at their independent reading level and it was inspiring to see the concentration and interest of the children as they pored over books in the class library.

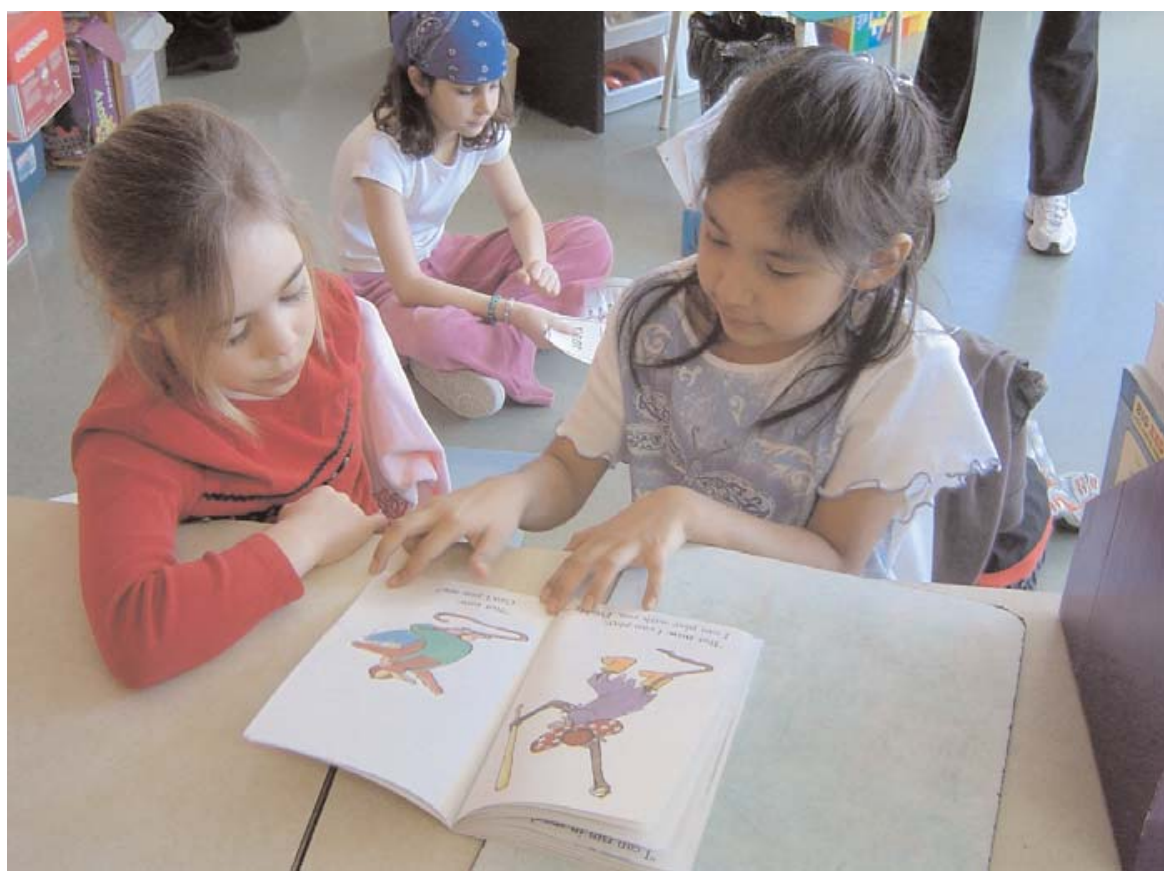

Fig. 7: Personal interest in reading

Building relationships was an important part of the Books and Buddies program. Cathy made a point of welcoming the younger buddies when they entered her classroom and kept a watchful eye on the interactions between the dyads, noting any inappropriate behaviors. The pleasure with which the children engaged in these literacy activities was evident in their expressions and body language. Smiling faces and bodies leaning toward each other were captured on film, but images do not adequately convey the hum of children's enjoyment as they learned together. I was constantly amazed with the children's focused attention and on-task behavior. They usually knew what to do and moved from one item to the next on their agenda. Cathy circulated to ensure they were on track; however, few needed to be redirected. 


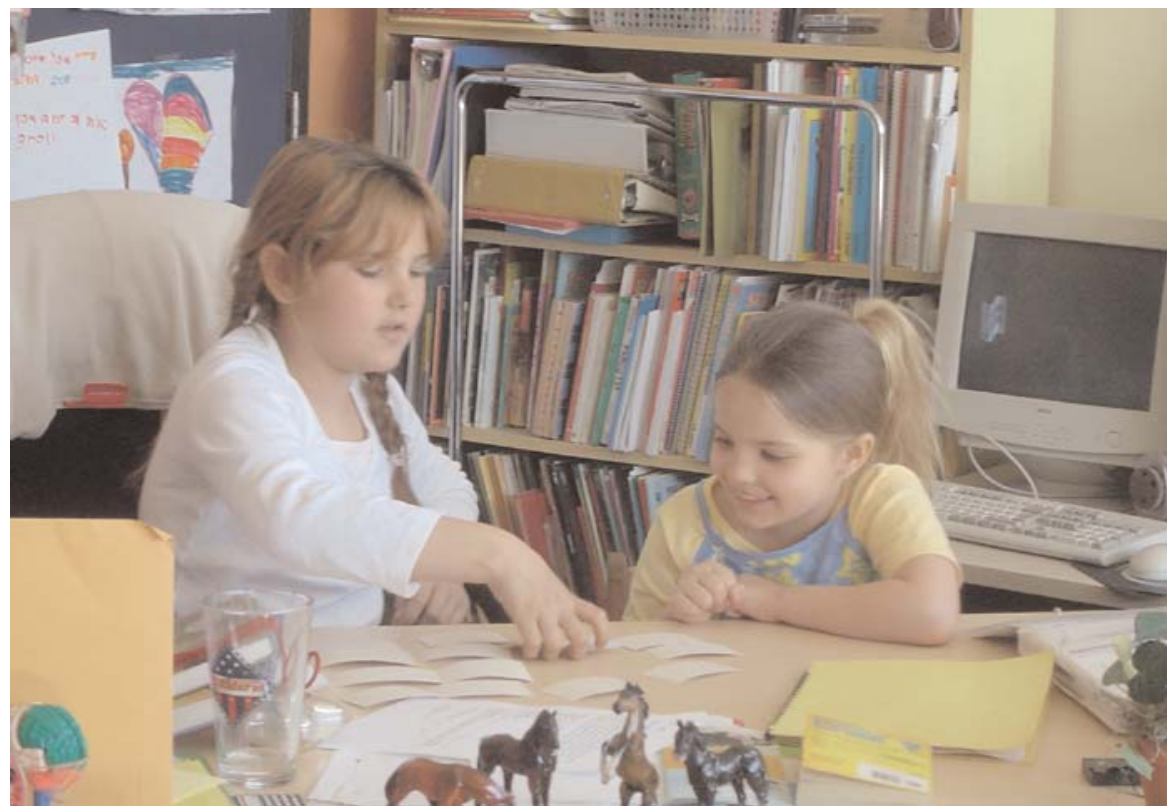

Fig. 8: Pleasure in learning

\section{Role of the Teacher}

The teacher's role in Book and Buddies was an essential component in making the program function efficiently and successfully. Collaboration with her colleague in the organization and structure of the program, preparation of materials, selection of pairs and scheduling the timetable was an important first step to getting the peer tutoring up and running for the year. Besides explaining procedures and modeling reading and teaching strategies, each teacher had to provide time for children to select and practice reading independent reading level texts. The teacher's responsibility was to observe and evaluate reading and social behaviors of individuals, dyads and the class as a whole, adapting and adjusting the program to accommodate students' needs. Providing individual and whole class feedback encouraged positive behaviors and afforded opportunities for children to address difficulties through joint problem-solving discussions. Each teacher supported children in dealing with inappropriate behavior by intervening when necessary. Ensuring that students understood their roles was a further responsibility of the teacher. 


\section{Role of the Students}

Students began by learning how to select and replace books in the classroom library. They learned a variety of reading strategies and practiced these strategies during in-class activities and home reading. Organizing materials, choosing an appropriate place to work and reviewing their agenda preceded teaching literacy skills to their partner. Other responsibilities included encouraging their buddy by providing positive feedback, keeping their partner focused, and addressing off-task behavior by independent problem solving. Writing story maps (summaries) of books they read with their partner was part of their role as a tutor and enabled Cathy to track their reading. Cathy taught and modeled each step in the peer tutoring program to ensure that every child knew how to proceed.

\section{Adaptation of the Program}

As part of her role in Books and Buddies, Cathy designed an adapted program to address the needs of children with learning challenges. She used a series of books about a large red dog named Clifford to support the development of children's literacy. These learners were unable to decode words using conventional strategies; instead, their strength lay in a holistic approach of memorizing a series of frequently used words to build a sight vocabulary. Children learned to identify these sight words through repetitive interactive games and activities followed by reading the designated words in the Clifford books. Cathy's students were given a booklet containing word cards and activities such as Bingo and Concentration along with a corresponding Clifford book. Cathy and Patricia, the teacher aide, trained them how to use the program and gave them opportunities to practice the vocabulary with more advanced peers from the class. 


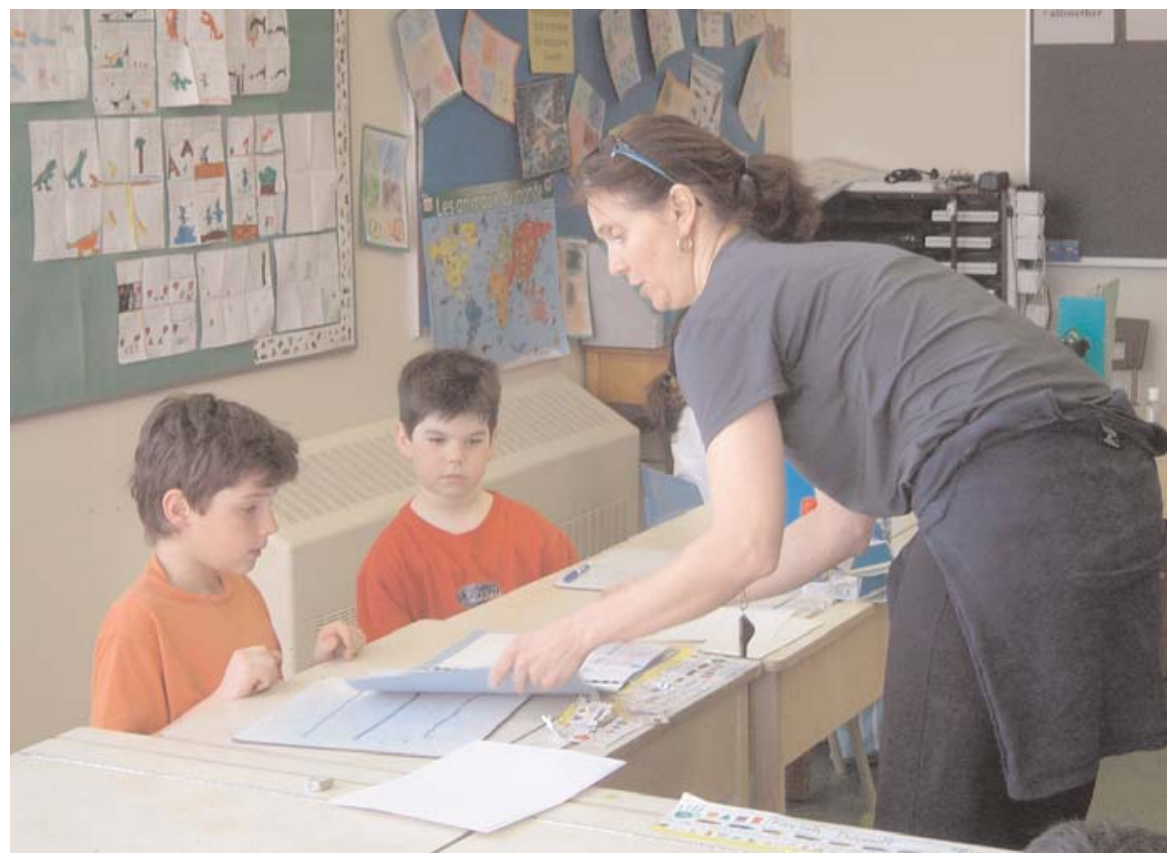

Fig. 9: Cathy explaining adapted program to Jean Marc and peer

Cathy's role in designing and implementing this "Clifford" remedial program required considerable time and effort on her part. She prepared materials, trained both the students and her teaching aide, observed the tutors carefully and offered corrective guidance as they enacted the revised program with their buddy. The Dolch list, a list of 220 high frequency words, provided an assurance of the appropriate level of challenge for both sets of learners. Extending inclusive opportunities such as the adapted peer tutoring program engaged special needs students by enabling them to fully participate in the academic program of the classroom (Giangreco, 2007).

\section{Effect of Adapted Program on a Child With Special Needs}

This adaptation to the peer tutoring program had a significant impact on children with learning challenges, especially on Jean Marc, a child who faced severe obstacles in learning to read and write. Jean Marc was a gentle, kind boy who was patient, responsible, and respectful. His eyes often reflected the complex challenges he faced as he struggled to read and write and he sometimes looked perplexed or 
exasperated by the overwhelming task of processing instructions. His learning disabilities were further complicated by the fact that French was his first language and he had no exposure to English books in his home.

Reading presented a tremendous challenge for Jean Marc. In September, an analysis of his reading skills indicated that he was unable to decode or encode words. During the first half of the year, Jean Marc would get frustrated with reading and would give up easily, but, with the new remedial program designed by Cathy, he was more motivated to persevere since he was able to draw on his strength of memorization rather than his weak decoding skills. Jean Marc initially worked on the literacy activities with a partner from third grade and subsequently presented these to Stephan, his learning partner in the peer tutoring program. Jean Marc stated that the "Clifford" program helped him "learn how to say words" and added that his secondand third-grade partners helped him as well.

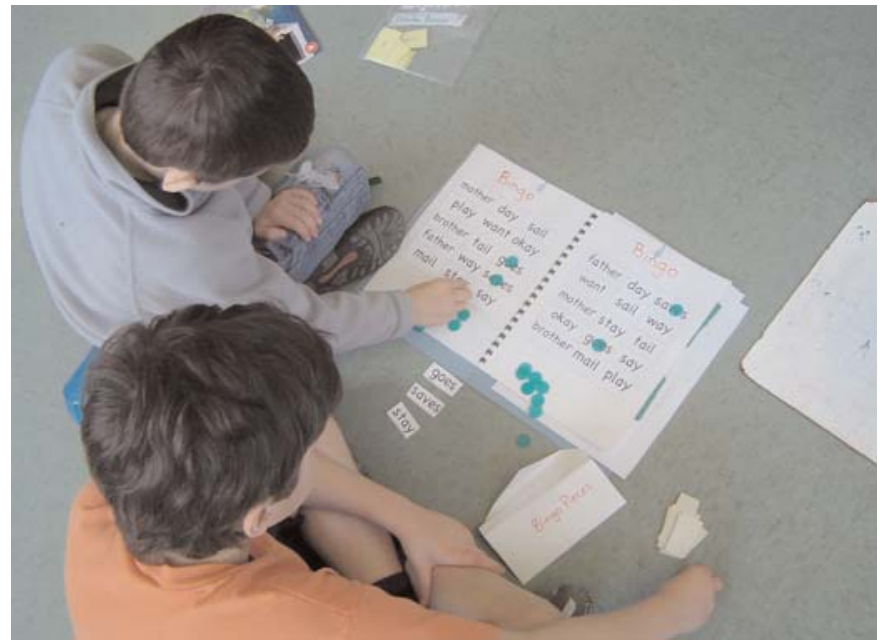

Fig. 10: Interactive Bingo required concentrated effort

He recognized that his friends helped to prepare him to use the remedial reading program more effectively with his little buddy than he could have done on his own by giving him the opportunity to practice what he had been taught by Patricia and Cathy.

The peer tutoring program had a significant effect on Jean Marc's perception of himself and contributed to his confident self-image as a learner and a person. In this safe learning environment (Hawkins, 2007), his reading began to improve and 
he indicated that "reading starts to be easy." He knew that he had a positive impact on another child and felt empowered by his teacher role. Jean Marc thought his grade one buddy, Stephan, liked him and knew he had helped him because "he can read longer books now."The first grade teacher admitted that the grade $2 / 3$ children played an important role by helping her students remain more focused through oneon-one attention, especially in this partnership that involved a troubled child who normally had difficulty concentrating.

This bright, kind-hearted child attained the goals of his Individual Educational Plan (IEP) and completed the year having learned some effective reading and writing strategies that he would be able to build on the following year. More importantly, Jean Marc left Cathy's class intact, a whole person who was wonderfully confident and saw himself as intelligent and able to help others.

\section{Conclusion}

This peer tutoring program improved academic achievement and behavior in students from both first and second/third grade classes by maximizing their engagement in literacy learning. Reading fluency and comprehension increased as students learned reading strategies and practiced reading at home and school. Of the eleven children in second grade, seven scored above level, three at level and only one experienced difficulty according to the Developmental Reading Assessment (DRA) scores from June. All of the children in third grade achieved the goals set out in their Individual Educational Plans and two of these students attained a DRA reading score of "at level."

The children loved choosing and reading books for pleasure and their roles as little teachers motivated them to be attentive, active learners. Their self-esteem rose as they learned positive social skills by providing appropriate feedback and addressing behavioral problems with their buddies. Through observation and individual interviews with six focus students, I could see that all students, including those with special needs, saw themselves as self-confident, effective readers and writers. For the most part, children were focused, on-task, and had a serious attitude toward this literacy event. I was inspired by their professional comportment and respectful attitude toward their partners and yet they maintained a playful sense of enjoyment as they interacted with their buddies. 


\section{Implications}

Rather than teaching literacy skills through repetitive drill and skill practice, teachers can balance their literacy program by embedding direct skill instruction within authentic contexts that challenge students to learn skills in meaningful situations that demand their use. Peer tutoring programs, when adapted to meet individual needs, can offer a form of critical pedagogy that not only engage all learners but, more importantly, provide a democratic form of education in which students with diverse ability levels can build on their strengths to develop competency. Jean Marc's summary of Cathy's belief in him is a poignant reminder of the impact she had on her students: "She says, 'Now I teach you everything. You may do it.'" A teacher's conviction that all children can learn, when combined with supportive, responsive instruction, can empower students to become autonomous learners as they assume leadership roles in organizing and directing literacy events in a self-regulated manner.

\section{References}

Barton-Arwood, S., Wehby, J., \& Falk, K. (2005). Reading instruction for elementary-age students with emotional and behavioural disorders: Academic and behavioural outcomes. Exceptional children, 72(1), pp. 7-27.

Bear, D. \& Templeton, S. (1998). Explorations in developmental spelling: Foundations for learning and teaching phonics, spelling and vocabulary. The Reading Teacher, 52 (3), 222-242.

Bruner, J. (1996). The culture of education. Cambridge, MA: Harvard University Press.

Charmaz, K. (1998). The grounded theory method: An explication And interpretation. In Robert M. Emerson (Ed.), Contemporary field research: A collection of readings. (pp.109-126). Prospect Heights, IL:Waveland.

Charmaz, K. (2006). Constructing grounded theory: A practical guide through qualitative analysis. Thousand Oaks, CA: Sage Publications.
Dahl, K., Scharer, P., Lawson, L. \& Grogan, P. (1999). Phonics instruction and student achievement in whole language first-grade classrooms. Reading Research Quarterly, 34(3), 312-331.

Fosnot, C. (2005). Constructivism: Theory, perspectives and practice. New York, NY: Teachers College Press.

Freppon, P. \& Dahl, K. (1998). Balanced instruction: Insights and considerations. Reading Research Quarterly, 33(2), 240-251.

Giangreco, M. (2007). Extending inclusive opportunities. Educational Leadership, 64(5), pp. 34-37.

Good, T. \& Brophy, J. (2003). Looking in classrooms. New York: Pearson.

Harris, K. \& Graham, S. (1994). Constructivism: Principles, paradigms, and integrations. The Journal of Special Education, 28(3), 233247.

Harry, B. \& Klingner, J. (2007). Discarding the deficit model. Educational Leadership, 64(5), pp. 16-21. 
Hawkins, V. (2007). Narrowing gaps for specialneeds students. Educational Leadership, 64(5), pp. 61-63.

Hehir, T. (2007). Confronting ableism. Educational Leadership, 64 (5), pp. 9-14.

Huie, K. \& Yahya, N. (2000). Learning to write in the primary grades: Experiences of English language learners and mainstream students. TESOL Journal, 12(1), 25- 31.

Kingsley, J. (2007). Literacy instruction in a constructivist elementary classroom: A narrative inquiry. Unpublished doctoral dissertation, McGill University.

Kreuger, E. (1996). The effects of cross-age peer tutoring versus cross-age reading buddies on first grader's reading achievement and sixth grader's self-esteem. Unpublished master's thesis, Bishop's University, Sherbrooke, Quebec, Canada.

Kreuger, E. \& Braun, B. (1998). Books and buddies: Peers tutoring peers. The Reading Teacher, 52, 410-423.

Kreuger, E. \& Townshend, N. (1997). Reading clubs boost second language first graders' reading achievement. The Reading Teacher, 51, 122-127.

Leland, C., Harste, J., Jackson, C. \& Youssef, O. (2001). Making teacher education critical. National Reading Conference Yearbook, 50, 382-393.

Love, D. and Fiedler, E. (2005). Examining the impact of the balanced instructional approach promoted by Reading First. Paper presented at AERA conference in Montreal, Quebec.

Maxwell, J. \& Miller, B. (1992). Two aspects of thought and two components of qualitative data analysis. Unpublished manuscript.

McMahon, B. (2003). Putting the elephant into the refrigerator: Student engagement, critical pedagogy and antiracist education. McGill Journal of Education, 39(2), pp. 257-273.

Ministère de l'Éducation (2001). Quebec Education Program: Preschool education and elementary education. Quebec, QC: Author.
Morgan, N. \& Saxton, J. (1994). Asking better questions: models, techniques and classroom activities for engaging students in learning. Markham, ON: Pembrooke Publishers.

Pardoe, S. (2000). Respect and the pursuit of 'symmetry' in researching literacy and student writing. In D. Barton, M. Hamilton \& R. Ivanic (Eds.), Situated literacies: Reading and writing in context (pp. 149-166). London: Routledge.

Pink, S. (2001). Doing visual ethnography. London:Sage.

Reeve, J., Jang, H., Carrell, D., Jeon, S., \& Barch, J. (2004). Enhancing students' engagement by increasing teachers' autonomy support. Motivation and Emotion, 28(2), pp. 147-169.

Riessman, C. (1993). Narrative analysis. Newbury Park, CA: Sage.

Ryan, R., \& Deci, E. (2000). Self-determination theory and the facilitation of intrinsic motivation, social development, and wellbeing. American Psychologist, 55(1), pp. 6878.

Saénz, L., Fuchs, L. \& Fuchs, D. (2005). Peer-assisted learning strategies for English language learners with learning disabilities. Exceptional Children, 71(3), pp. 231-247.

Schwandt, T. (2003). Three epistemological stances for qualitative inquiry: Interpretism, hermeneutics, and social constructivism. In N. Denzin \& Y. Lincoln (Eds.), The landscape of qualitative research: Theories and issues pp. 292-331. Thousand Oaks, CA: Sage Publications.

Street, B. (1984). Literacy in Theory and Practice. Cambridge: Cambridge University Press.

Tompkins, G. (2006). Literacy for the $21^{\text {st }}$ century: A balanced approach. Upper Saddle River, $\mathrm{NJ}$ : Pearson Education.

Twiss, L. (1996). Diverse learners in the classroom: Innovative literacy practices for ESL learners. The Reading Teacher, 49(5), 412414.

Vibert, A. \& Shields, C. (2003). Approaches to student engagement: Does ideology matter? McGill Journal of Education, 39(2), pp. 221240. 
Von Glaserfeld, E. (2005). Introduction: Aspects of constructivism. In C. Fosnot (Ed.), Constructivism: Theory, perspectives and practice (pp. 3-7). New York: Teachers College Press.

Wells, G. (1999). Dialogic inquiry in education: Towards a sociocultural practice and theory of education. New York: Cambridge University Press.
Wells, G. (2000). Dialogic inquiry in education: Building on the legacy of Vygotsky. In In C. Lee \& P.Smagorinsky (Eds.), Vygotskian perspectives on literacy research: Constructing meaning through collaborative inquiry. New York: Cambridge University Press.

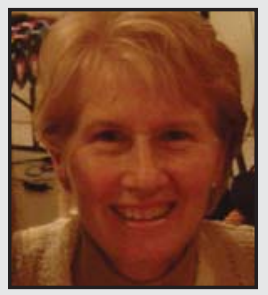

Joanne Kingsley is an Assistant Professor at Bishop's University where she teaches pre-service teachers in the School of Education. She has just completed her Ph.D in the Departement of Integrated Studies in Education in the Faculty of Education at McGill University. She taught Language Arts at the secondary and elementary levels for thirty years during which time she served on advisory committees in the Ministry of Education, Montreal, Quebec.

\section{LINK TO:}

http://www.ubishops.ca/ 